\title{
High-Resolution Melting Curve Analysis as a Tool for Detection of SEC23B Gene Mutation Causing Congenital Dyserythropoietic Anemia Type II in Indian population
}

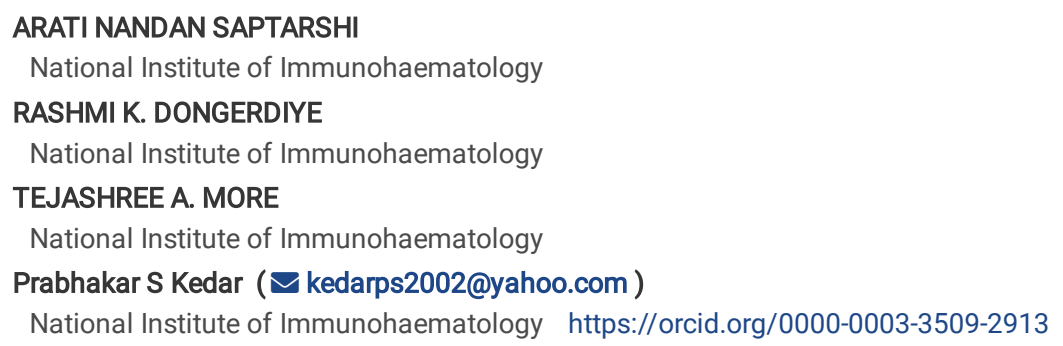




\begin{abstract}
Background: Congenital dyserythropoietic anemias (CDAs) are a very rare and heterogeneous group of disorders characterized by ineffective erythropoiesis. CDA II is caused by mutations in the SEC23B gene. The most common mutation reported in India is c.1385A>G, p.Y462C. There is no simple and cost-effective confirmatory diagnostic test available for $\mathrm{CDA}$, and therefore, many patients remain undiagnosed. High-resolution melting (HRM) analysis is a polymerase chain reaction (PCR) based technique applied to identify genetic differences and scan nucleic acid sequences. HRM can be used to rapidly screen the common mutation causing CDA II in the Indian population.
\end{abstract}

Objective: To study the use of High-Resolution Melting Curve Analysis to detect common mutation causing CDA II in the Indian population.

Method:10 Indian families having SEC23B (Y462C) mutation causing CDA II are considered for this study. HRM was used to check the presence of Y462C mutation. To verify the reliability of the HRM analysis, we compared results with the results of Sanger sequencing. This helped us to confirm the diagnosis.

Results: We have described clinical, hematological, and genetic data of ten patients suffering from CDAll. According to HRM and Sanger sequencing, a homozygous SEC23B (Y462C) mutation was present in all patients, whereas a heterozygous Y462C mutation was present in their parents.

Conclusion: Our data showed that High-Resolution Melting (HRM) analysis could be used to rapidly screen common SEC23B mutations that cause CDA II in the Indian population.HRM technique leads to an accurate diagnosis of CDA II patients and does not need further diagnostic workup.

\title{
Introduction
}

Congenital dyserythropoietic anemias (CDA) are a rare and heterogeneous group of disorders. CDAs are characterized by ineffective erythropoiesis, morphological abnormalities of erythroblasts (bi/ multinucleated erythroblast, internuclear bridges, erythroid hyperplasia), haemolysis, and hypoglycosylation of red blood cell membrane proteins. Depending on erythroid maturation and precursors involved, three major types of CDA (I, II, III) are identified. Other variants of CDA like transcription factor-related CDA include CDA type IV and X-linked thrombocytopenia with or without dyserythropoietic anemia (XLTDA). The CDA associated with Majeed syndrome is also known. The causative genes are CDAN1, C15ORF41(CDIN2), SEC23B, KIF23, KLF1, GATA1, and LPIN2 [1].The Patients suffering from CDA are characterized with anemia of variable degree, pallor, recurrent jaundice, hepatomegaly, splenomegaly, gall stones. In some cases, patients are transfusion-dependent, while in some cases, transfusion is less frequently required, and patients are asymptomatic [2]. Light and electron microscopic analysis of bone marrow samples [3], SDS-PAGE exclusively for CDA type II, and genetic analysis using Sanger sequencing and nextgeneration sequencing is currently used for the diagnosis of CDA.

Congenital Dyserythropoietic Anemia type II (OMIM: 224100) is the most common type of CDA. The genetic defect of CDA type II is due to mutations in the SEC23B gene (encoding COPII) [4]. SEC23B gene (OMIM: 610512) is located on chromosome 20p11.23. It is involved in providing instructions for the making of one component of coat protein complex II (COPII). COPII is a large group of interacting proteins that function in the formation of vesicles. Vesicles are small sac-like structures that are involved in the transportation of proteins and other materials in cells. COPII triggers the formation of vesicles in the endoplasmic reticulum (ER). It plays a vital role in protein processing and transportation. Proteins that are destined to be secreted are carried by COPII vesicles. Endoplasmic reticulum (ER)-to-Golgi trafficking is disturbed due to abnormalities in the SEC23B gene. This affects different glycosylation pathways and ultimately accounts for the cellular phenotype observed in CDAll [5].

SEC23B mutations are inherited in an autosomal recessive pattern. So far, only 16 patients of congenital dyserythropoietic anemia type II from India have been described in the literature: 6 of the patients diagnosed based on bone marrow light microscopy [6], 10 North Indian patients having Y462C mutation in exon 12 of $S E C 23 B$ gene [7-8]. There is a possibility of more patients suffering from CDA in the Indian population. But, the data is not available because of difficulties in diagnosis. Biochemical methods like the anti-CD44 antibody binding test, along with bone marrow microscopy and molecular tests, will be helpful [9-10]. More than 120 mutations have been identified in the SEC23B gene that causes CDA Type II. The most common mutation in the Indian population is c.1385A>G, p.Y462C [11]. Many patients with CDA remain undiagnosed because of a lack of simple, confirmatory diagnostic methods.

In the Eosin-5'-Maleimide assay (EMA), patients suffering from hereditary spherocytosis (HS) and CDA type II show decreased mean channel fluorescence (MCF). Thus, many cases of CDA type II are misdiagnosed as cases of HS. In CDA type II patients, anti-CD44 antibody binding to red blood cells is raised compared to normal healthy individuals and HS patients. We used the Eosin-5'-Maleimide assay (EMA) by flow cytometry to diagnose hereditary spherocytosis and CDA type II. We have further used an anti-CD44 antibody binding assay to suspect the diagnosis of CDA II in patients who have shown low mean channel fluorescence in the EMA test.

High-resolution melting (HRM) curve analysis is a polymerase chain reaction (PCR) based technique applied to identify genetic differences and scan nucleic acid sequences. The properties of DNA such as length, sequence, composition, GC content, and heterozygosity are responsible for the melting curve. The significant information about the genotype can be obtained by these melting curve profiles, which allows an analysis of mutations and polymorphisms. The precision and accuracy of the HRM method are dependent on the fluorescent dye used along with the instrument and software in the analysis [12]. HRM analysis gives reproducible and rapid results though it is not used in routine clinical practice [13]. In this study, we have developed the HRM method to detect common SEC23Bgene mutation causing CDA type II in the Indian population.

\section{Materials And Methods}

\subsection{Blood collection, measurement of hematological parameters, and case history}

Page 2/10 
A total of 10 suspected patients of CDA were referred to our haematogenetics laboratory of the National Institute of Immunohematology (NIIH), KEM Hospital, Mumbai, India. All patients were of Indian origin and were from genetically unrelated families. The available family members of 10 patients were included in this study. With the approval of ICMR- National Institute of Immunohematology- Ethics Committee guidelines, we took written informed consent from all the patients and their family members. We reviewed the patient's family history, clinical, morphological, and laboratory data. The CDA was suspected based on clinical findings and bone marrow analysis. The complete blood count (CBC) using the automated hematology analyzer Sysmex XN (Sysmex corporation) software and morphological examination of red blood cells was performed. The confirmation of the diagnosis of CDA was done by molecular analysis using High-Resolution Melting Curve and Sanger sequencing.

\subsection{Eosin $5^{\prime}$ Maleimide (EMA) binding assay}

$5 \mu \mathrm{L}$ washed packed red blood cells from all patients, and healthy controls were mixed with $25 \mu \mathrm{L}$ of EMA dye (0.5 mg/mL in PBS) and incubated for an hour in the dark at room temperature. Phosphate Buffer Saline-bovine serum albumin (PBS-BSA) solution was used to wash EMA dye-labeled RBCs. Washed RBCs were then resuspended in $500 \mu \mathrm{L}$ of PBS-BSA solution. $50 \mu \mathrm{L}$ of RBCs labelled with EMA were resuspended in $700 \mu \mathrm{L}$ of $0.5 \%$ PBS-BSA solution for analysis on BD FACSAria $^{T M}$ Fusion Flow Cytometer. Results were expressed in Mean Channel Fluorescence (MCF) described earlier for the diagnosis of hereditary spherocytosis [14]. In the cases of CDA type II patients, low or borderline MCF was observed [8-9].

\subsection{CD44 antibody binding assay}

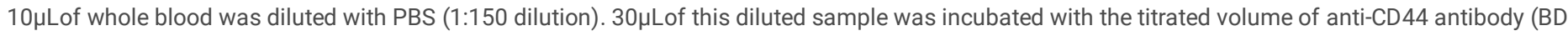
Biosciences) in the dark at room temperature for $20 \mathrm{~min}$. CD44 labelled RBCs were then washed with Phosphate Buffer Saline (PBS) and resuspended in 300 $\mu \mathrm{L}$ of PBS and used for analysis on BD FACSAria ${ }^{\mathrm{TM}}$ Fusion Flow Cytometer, and results were expressed in MCF as described earlier [9].

\subsection{Isolation of DNA and mutational analysis of SEC23B gene}

FlexiGene kit was used for the isolation of genomic DNA from peripheral blood. Amplification of DNA for exon 12 of $S E C 23 B$ gene was carried out using oligonucleotides primers [Exon-12F: 5'TCACAGTGGCTGAGGAAAAG 3' and Exon-12R: $5^{\prime}$ TGACTCCGACTAAACCCTTG 3']. The PCR conditions were: 950 $\mathrm{C}$ for 5 $\min \left(94^{\circ} \mathrm{C}\right.$ for $20 \mathrm{sec}, 58^{\circ} \mathrm{C}$ for $20 \mathrm{sec}, 72^{\circ} \mathrm{C}$ for $\left.20 \mathrm{sec}\right)$ for $35 \mathrm{cycles}$ and final extension at $72^{\circ} \mathrm{C}$ for 5 min. QIAquick Gel Extraction Kit was used to purify the amplicons further, and purified products were used for mutation analysis. ABI PRISM BigDye Terminator Cycle Sequencing Ready Kit was used for sequencing of purified PCR products, and they were run on an ABIPrism 3730xl Genetic Analyzer (Applied Biosystems, USA). CHROMAS software v2.6.6 was used to analyze the obtained chromatograms.

\subsection{High-Resolution Melting (HRM) analysis for screening of SEC23B-Y462C mutation}

Real-time PCR (ABI step one plus) was used to perform High-Resolution Melting (HRM) assay for the screening of SEC23B-Y462C mutation. 10.0 $\mu \mathrm{L}$ of HRM Master Mix manufactured by MeltDoctor ${ }^{\mathrm{TM}}, 0.4 \mu \mathrm{L}$ of forward primer (10 pmoles) [Exon-12F: 5'TCACAGTGGCT GAGGAAAAG3"and $0.4 \mu \mathrm{L}$ of reverse primer (10 pmoles) [Exon-12R: 5' TGACTCCGACTAAACCCTTG 3']., $2.0 \mu \mathrm{L}$ of DNA having concentration 50-100 ng, $7.2 \mu \mathrm{L}$ of HPLC water making a reaction mixture of $20.0 \mu$ Lwas used for the assay. The cycling conditions were as follows: denaturation at $95^{\circ} \mathrm{C}$ for $10 \mathrm{~min}\left(95^{\circ} \mathrm{C}\right.$ for $15 \mathrm{sec}, 60^{\circ} \mathrm{C}$ for $\left.1 \mathrm{~min}\right)$ for $40 \mathrm{cycles}$. The temperature was raised to $97^{\circ} \mathrm{C}$ following continuous fluorescence detection of 25 acquisitions for the development of melting curves [12]. StepOne Software v2.3 was used for the completion of all steps by using HRM Software v3.0.1 to carry out an analysis.

\section{Results}

\subsection{Clinical Data}

10 CDA patients ( 8 males and 2 females) were included in our study. Their ages ranged from 3 months to 33 years. The hematological, biochemical, and clinical manifestations in these patients are summarized in Table-1. The clinical picture of all ten patients showed recurrent jaundice, severe anemia, hepatosplenomegaly of varying degrees, and most of the patients presented with weakness, fatigue, recurrent stomach aches. Serum ferritin and lactate dehydrogenase (LDH)activity was increased in all the patients. The patient's peripheral blood smear showed hypochromic cells, teardrop cells, and a few spherocytes, and the bone marrow smear showed erythroid hyperplasia, few bi \& multinucleated erythroblasts, and mild dyserythropoiesis. Index case from family 1 had short stature and cushingoid features. The index case from family 2 had antinuclear antibody (ANA) positive, and the index case of family 8 had a congenital disorder of glycosylation along with congenital dyserythropoietic anemia.

\subsection{Flow cytometric analysis of EMA binding assay and anti-CD44 antibody binding assay}

The significant decrease in MCF using EMA binding assay suspected CDA in 10 cases, as shown in Table-1. (Normal range of healthy control: 900 - 1300 MCF units). The anti- CD44 antibody binding test using flow cytometric analysis was performed; positive results were obtained based on elevated mean channel fluorescence values compared to normal healthy individuals. However, MCF readings of parents of all the patients were normal for the EMA test and the antiCD44 antibody binding test. All patients with CDA showed almost twice MCF in the anti-CD44 antibody binding test than normal healthy individuals (Fig. 2).

\subsection{Sanger sequencing for confirmation of SEC23B-Y462C mutation}

The Sanger sequencing was performed to confirm the SEC23B - Y462C mutation results obtained by HRM analysis. Sanger sequencing revealed substitution of nucleotide in exon 12 at codon 462 (TAT $\diamond$ TGT), which corresponds to homozygous Tyr462Cys (Y462C) mutation in all patients (Fig. 3A), and their parents and some of the family members showed heterozygous Y462C genotype for CDA having normal phenotype (Fig. 3B) (Table 2). There was no other mutation 
present in the SEC23B gene in any of the patients. The sensitivity and specificity for this HRM curve assay are $95 \%$ and $99 \%$, respectively. DNA sequencing data showed that High-Resolution Melting (HRM) analysis could be used for rapid screening of common SEC23B mutation that causes CDA II in the Indian population.HRM technique leads to an accurate diagnosis of CDA II and does not need further diagnostic workup.

Table 1

Haematological, Biochemical and Clinical Profile of 10 Patients with CDA type II

\begin{tabular}{|c|c|c|c|c|c|c|c|c|c|c|c|}
\hline Family & Proband & $\begin{array}{l}\text { Age at } \\
\text { diagnosis/ } \\
\text { Sex }\end{array}$ & $\begin{array}{l}\text { RBC } \\
\left(x 10^{6} / \mathrm{ul}\right)\end{array}$ & $\begin{array}{l}\mathrm{Hb} \\
(\mathrm{g} / \mathrm{dL})\end{array}$ & $\begin{array}{l}\mathrm{HCT} \\
(\%)\end{array}$ & $\begin{array}{l}\text { MCV } \\
\text { (fl) }\end{array}$ & $\begin{array}{l}\mathrm{MCHC} \\
(\mathrm{g} / \mathrm{dL})\end{array}$ & $\begin{array}{l}\text { RDW } \\
\text { (\%) }\end{array}$ & $\begin{array}{l}\text { Retic } \\
\text { Count } \\
(\%)\end{array}$ & BM-LM & $\begin{array}{l}\text { Presenting } \\
\text { Symptoms }\end{array}$ \\
\hline F1 & $\|-2$ & $5 Y / M$ & 1.89 & 4.3 & 13.8 & 73 & 31.2 & 29.7 & 3 & $\begin{array}{l}\text { Erythroid hyperplasia, } \\
\text { few bi \& multinucleated } \\
\text { erythroblasts, occasional } \\
\text { karyorrhectic forms, mild } \\
\text { dyserythropoiesis }\end{array}$ & $\begin{array}{l}\text { Chronic anemia, } \\
\text { Hepato- } \\
\text { Splenomegaly }\end{array}$ \\
\hline F2 & II - 1 & $33 Y / M$ & 2.16 & 5.8 & 17.3 & 80.1 & 33.5 & 23 & 0.9 & $\begin{array}{l}\text { Erythroid hyperplasia, } \\
\text { binucleated erythroblasts, } \\
\text { dyserythropoiesis }\end{array}$ & $\begin{array}{l}\text { Pallor, lcterus, } \\
\text { anemia } \\
\text { Cholelithiasis, } \\
\text { haemolytic facies }\end{array}$ \\
\hline F3 & $\|-1$ & $3 \mathrm{~m} / \mathrm{M}$ & 2.7 & 7.5 & 20.7 & 76.7 & 36.2 & 15.2 & 9 & Not Done & $\begin{array}{l}\text { Severe anemia, } \\
\text { hepato- } \\
\text { splenomegaly, } \\
\text { neonatal jaundice }\end{array}$ \\
\hline $\mathrm{F} 4$ & II - 2 & $9 \mathrm{Y} / \mathrm{F}$ & 2.64 & 6.9 & 19.1 & 72.3 & 36.1 & 27.3 & 8 & $\begin{array}{l}\text { Erythroid Hyperplasia, } \\
\text { binucleated erythroblasts }\end{array}$ & $\begin{array}{l}\text { Chronic anemia, } \\
\text { Hyperbilirubinemia }\end{array}$ \\
\hline F5 & $11-3$ & $12 \mathrm{Y} / \mathrm{M}$ & 2.66 & 7 & 21.5 & 80.8 & 32.6 & 30 & 4 & Not Done & $\begin{array}{l}\text { Severe anemia, } \\
\text { Icterus }\end{array}$ \\
\hline F6 & $\|-1$ & $9 \mathrm{Y} / \mathrm{M}$ & 1.65 & 6.2 & 18.3 & 110.9 & 33.9 & 20.7 & 2.4 & $\begin{array}{l}\text { Erythroid Hyperplasia, large } \\
\text { number of bilobed erythroid } \\
\text { cells,some nuclear bridging }\end{array}$ & $\begin{array}{l}\text { Severe anemia, } \\
\text { Neonatal Jaundice, } \\
\text { splenomegaly }\end{array}$ \\
\hline F7 & II - 3 & $13 Y / M$ & 3.33 & 8.3 & 24.4 & 73.3 & 34 & 24.8 & 1.3 & Not Done & $\begin{array}{l}\text { Chronic haemolytic } \\
\text { anemia, Icterus, } \\
\text { Pallor, } \\
\text { hepatosplenomegal }\end{array}$ \\
\hline & II - 2 & $18 Y / F$ & 2.94 & 8.8 & 24.1 & 82 & 36.5 & 22.1 & 1.6 & $\begin{array}{l}\text { Erythroid hyperplasia, mild } \\
\text { dyserythropoiesis, } \\
\text { multinucleated erythroblasts, } \\
\text { karyorrhexis, nuclear budding }\end{array}$ & $\begin{array}{l}\text { Severe anemia, } \\
\text { recurrent jaundice, } \\
\text { pallor, chipmunk } \\
\text { facies }\end{array}$ \\
\hline F8 & II - 3 & $15 Y / M$ & 3.68 & 9.9 & 32 & 87 & 30.9 & 26 & 5 & Not Done & $\begin{array}{l}\text { Anemia, pallor, } \\
\text { icterus, moderate } \\
\text { splenomegaly }\end{array}$ \\
\hline F9 & II - 2 & $12 \mathrm{Y} / \mathrm{M}$ & 3.0 & 7.4 & 22.5 & 75 & 32.9 & 21.7 & 0.1 & Dyserythropoieticnormoblasts & $\begin{array}{l}\text { Severe pallor, severє } \\
\text { anemia, neonatal } \\
\text { jaundice, } \\
\text { splenomegaly }\end{array}$ \\
\hline
\end{tabular}

Abbreviations: BM-LM: Bone Marrow analysis using Light Microscopy, EMA: Eosin-5'-Maleimide, MCF: Mean Channel Fluorescence 
Table 2

Genotyping of SEC23B - Y462C mutation in patients with CDA and family members using HRM analysis and Sanger sequencing

\begin{tabular}{|c|c|c|c|c|c|c|}
\hline Family & Number & Relationship & Clinical Diagnosis & Nucleotide change & & Amino acid change \\
\hline & & & & Sanger's Sequencing & HRM analysis & \\
\hline \multirow[t]{4}{*}{ F1 } & I- 1 & Mother & Normal & TAT/TGT & TAT/TGT & N/Y462C \\
\hline & $1-2$ & Father & Normal & TAT/TGT & TAT/TGT & $\mathrm{N} / \mathrm{Y} 462 \mathrm{C}$ \\
\hline & $\|-1$ & Daughter & Normal & TAT/TAT & TAT/TAT & $\mathrm{N} / \mathrm{N}$ \\
\hline & $\| \mathrm{I}-2$ & Son & CDA & TGT/TGT & TGT/TGT & Y462C/Y462C \\
\hline \multirow[t]{5}{*}{ F2 } & I- 1 & Mother & Normal & TAT/TGT & TAT/TGT & N/Y462C \\
\hline & $1-2$ & Father & Normal & TAT/TGT & TAT/TGT & $\mathrm{N} / \mathrm{Y} 462 \mathrm{C}$ \\
\hline & $\|-1$ & Son & CDA & TGT/TGT & TGT/TGT & Y462C/Y462C \\
\hline & $\|-2$ & Daughter & Normal & ND & ND & ND \\
\hline & II - 3 & Daughter & Normal & ND & ND & ND \\
\hline \multirow[t]{3}{*}{ F3 } & $\mathrm{I}-1$ & Mother & Normal & TAT/TGT & TAT/TGT & $\mathrm{N} / \mathrm{Y} 462 \mathrm{C}$ \\
\hline & $1-2$ & Father & Normal & TAT/TGT & TAT/TGT & N/Y462C \\
\hline & $\|$ - 1 & Son & CDA & TGT/TGT & TGT/TGT & Y462C/Y462C \\
\hline \multirow[t]{5}{*}{ F4 } & $\mathrm{I}-1$ & Mother & Normal & TAT/TGT & TAT/TGT & $\mathrm{N} / \mathrm{Y} 462 \mathrm{C}$ \\
\hline & $1-2$ & Father & Normal & TAT/TGT & TAT/TGT & $\mathrm{N} / \mathrm{Y} 462 \mathrm{C}$ \\
\hline & II- 1 & Daughter & Normal & TAT/TGT & TAT/TGT & $\mathrm{N} / \mathrm{Y} 462 \mathrm{C}$ \\
\hline & $\|-2$ & Daughter & CDA & TGT/TGT & TGT/TGT & Y462C/Y462C \\
\hline & II - 3 & Son & Normal & TAT/TGT & TAT/TGT & $\mathrm{N} / \mathrm{Y} 462 \mathrm{C}$ \\
\hline \multirow[t]{5}{*}{ F5 } & $\mathrm{I}-1$ & Mother & Normal & TAT/TGT & TAT/TGT & $\mathrm{N} / \mathrm{Y} 462 \mathrm{C}$ \\
\hline & $1-2$ & Father & Normal & TAT/TGT & TAT/TGT & $\mathrm{N} / \mathrm{Y} 462 \mathrm{C}$ \\
\hline & $\|-1$ & Son & Normal & TAT/TAT & TAT/TAT & $\mathrm{N} / \mathrm{N}$ \\
\hline & $\|-2$ & Daughter & Normal & ND & ND & ND \\
\hline & II - 3 & Son & CDA & TGT/TGT & TGT/TGT & Y462C/Y462C \\
\hline \multirow[t]{3}{*}{ F6 } & $I-1$ & Mother & Normal & TAT/ TGT & TAT/ TGT & $\mathrm{N} / \mathrm{Y} 462 \mathrm{C}$ \\
\hline & $1-2$ & Father & Normal & TAT/ TGT & TAT/ TGT & $\mathrm{N} / \mathrm{Y} 462 \mathrm{C}$ \\
\hline & $\| 1$ & Son & CDA & TGT/ TGT & TGT/ TGT & Y462C/Y462C \\
\hline \multirow[t]{5}{*}{ F7 } & $I-1$ & Mother & Normal & TAT/ TGT & TAT/ TGT & $\mathrm{N} / \mathrm{Y} 462 \mathrm{C}$ \\
\hline & $1-2$ & Father & Normal & TAT/ TGT & TAT/ TGT & $\mathrm{N} / \mathrm{Y} 462 \mathrm{C}$ \\
\hline & $\|-1$ & Daughter & Normal & TAT/ TGT & TAT/ TGT & $\mathrm{N} / \mathrm{Y} 462 \mathrm{C}$ \\
\hline & $\|-2$ & Daughter & CDA & TGT/ TGT & TGT/ TGT & Y462C/Y462C \\
\hline & II - 3 & Son & CDA & TGT/ TGT & TGT/ TGT & Y462C/Y462C \\
\hline \multirow[t]{4}{*}{ F8 } & $\mathrm{I}-1$ & Mother & Normal & TAT/ TGT & TAT/ TGT & $\mathrm{N} / \mathrm{Y} 462 \mathrm{C}$ \\
\hline & $1-2$ & Father & Normal & TAT/ TGT & TAT/ TGT & $\mathrm{N} / \mathrm{Y} 462 \mathrm{C}$ \\
\hline & $\|-1$ & Son & CDA & TGT/ TGT & TGT/ TGT & Y462C/Y462C \\
\hline & II - 2 & Son & Normal & TAT/ TGT & TAT/ TGT & $\mathrm{N} / \mathrm{Y} 462 \mathrm{C}$ \\
\hline
\end{tabular}




\begin{tabular}{|lllllll|}
\hline Family & Number & Relationship & Clinical Diagnosis & Nucleotide change & & Amino acid change \\
\hline F9 & $1-1$ & Mother & Normal & TAT/ TGT & TAT/ TGT & N/Y462C \\
& $1-2$ & Father & Normal & TAT/ TGT & TAT/ TGT & N/Y462C \\
& $I-1$ & Daughter & Normal & TAT/ TGT & TAT/ TGT & N/Y462C \\
& II-2 & Son & CDA & TGT/ TGT & TGT/ TGT & Y462C/Y462C \\
& & & & & \\
& & & & & \\
& & & & & \\
\hline
\end{tabular}

\subsection{HRM screening of SEC23B-Y462C mutation}

Results of HRM analysis showed the presence of homozygous c.1385A>G, (p.Y462C) in all index cases. Analysis was performed by HRM analysis software. HRM profile for genotypic differentiation in the Melting curve showing homozygous (Y462C), heterozygous and wild type is shown in Fig. 3C, and difference plot showing homozygous (Y462C), heterozygous and wild type is shown in Fig. 3D. The high-resolution melting curves and difference plots of patients showed the homozygous mutation, and their parents showed the heterozygous mutation. On the RT-PCR screen of HRM analysis, all patients showed the prominent peak of homozygous Y462C mutations, and their parents showed the heterozygous peak of Y462C genotypes. All these CDA cases were confirmed by an anti-CD44 antibody binding test by flow cytometry and molecular diagnosis. The sensitivity and specificity for this HRM curve assay are $95 \%$ and $99 \%$, respectively. HRM technique leads to an accurate diagnosis in CDAll patients and does not need further diagnostic workup.

\section{Discussion}

This study developed an HRM analysis method to detect c.1385A>G, (p.Y462C) mutation in the SEC23B gene. High-resolution melting (HRM) analysis is a polymerase chain reaction-based technique that identifies genetic differences and scans nucleic acid sequences. According to the HRM curve analysis, all the CDA patients had homozygous Y462C mutation, and their parents and a few family members had heterozygousY462C mutation. We used Sanger sequencing to verify the results obtained by the HRM analysis. This confirmed the efficiency of HRM analysis in screening common SEC23Bmutations in CDA patients. SEC23B variations are currently detected using conventional methods like PCR-SSCP, allele-specific amplification (ASA), and Sanger sequencing [8]. All of these methods are lengthy and costly. They involve open tube assays which need processing after PCR. The post-PCR processing includes electrophoresis and/or sequencing. This method makes it very laborious. Further, PCR products need to be transferred for further analysis. In this, there is a high risk of contamination. Wittwer and his colleagues developed a high-resolution melting curve analysis of amplified products using dsDNA dye in the late 1990s [1516]. The advantage of the HRM method is that the same reaction tube is used for amplification and detection steps. This eliminates possible post-PCR contaminations that can occur in conventional methods. For the laboratories with a large number of samples for analysis or laboratories with less funding, it is challenging to do DNA sequencing even though now the cost for the same is relatively low. After isolating and extracting genomic DNA, the HRM analysis takes only a few hours for completion, and visually comparing the melting curves on the RT-PCR screen is sufficient for diagnosis. This makes the process fast and has high throughput. Analysis using a High-Resolution Melting curve is economically beneficial as the technique has minimal requirements [17]. The cost of saturating DNA dye is less than the PCR reagents, although a thermal cycler is capable of measuring real-time fluorescence. Using the HRM method, identifying single-base changes that cause heterozygosity is possible. All these CDA cases were confirmed by an anti-CD44 antibody binding test by flow cytometry and molecular diagnosis [9]. The sensitivity and specificity for this HRM curve assay are $95 \%$ and $99 \%$, respectively [18].

\section{Conclusions}

Considering these advantages of HRM, we have developed a protocol for studying the common mutation (SEC23B-Y462C) causing congenital dyserythropoietic anemia type II in the Indian population. Our data showed that High-Resolution Melting (HRM) analysis could be used for rapid screening of common SEC23B mutation that causes CDAll in the Indian population. HRM technique leads to an accurate diagnosis in CDAll patients and does not need further diagnostic workup. Earlier incorporation of HRM technique for diagnosis of CDAll in Indian patients will improve patient care and enable genetic counselling and prenatal diagnosis.

\section{What is already known?}

CDA is a rare disorder characterized by ineffective erythropoiesis with a high prevalence of c.1385A $>\mathrm{G}$ (p.Tyr462Cys) mutation in exon 12 of $S E C 23 B$ gene in the Indian population. Less number of patients are diagnosed because of a lack of confirmatory diagnostic tests. Molecular diagnosis using Next Generation Sequencing and Sanger sequencing is costly and time-consuming.

\section{What does this study add?}

We have developed a high-resolution melting curve analysis protocol using real-time PCR for molecular diagnosis of patients suffering from CDA having c. $1385 \mathrm{~A}>\mathrm{G}$ mutation common in the Indian population. This study shows that High-Resolution Melting curve analysis is an accurate, sensitive method and can be used for rapid screening of CDA patients and carrier detection for SEC23B mutations. With the help of all this, accurate and fast diagnosis, medical management, genetic counselling, and prenatal diagnosis for congenital dyserythropoietic anemia is now possible. 


\section{Declarations}

\section{ACKNOWLEDGMENTS:}

We would like to thank patients and family members for their cooperation and participation in this study. This study was performed with the financial support of the Indian Council of Medical Research New Delhi and Lady Tata Memorial Trust.

\section{CONFLICT OF INTEREST}

The authors have no competing interests.

\section{AUTHOR CONTRIBUTIONS}

AS analyzed data and was involved in the conceptualization of the work. PK, AS designed, conducted, analyzed data, and wrote the manuscript. RD, TM, and AS performed laboratory work. RD and AS collected clinical data. PK conducted supervision and writing review.

\section{CONSENT FOR PUBLICATION}

We obtained written informed consent to identify images or other personal or clinical details from all the participants. In the case of a minor, we obtained written informed consent for publications identifying pictures or additional clinical information from the parents or legal guardians

\section{FUNDING INFORMATION:}

This study was performed with the financial support of the Indian Council of Medical Research New Delhi. The funding body played no role in the design of the study and collection, analysis, and interpretation of data and in writing the manuscript.

\section{ETHICAL APPROVAL:}

This study was approved by the Ethics Committee of the Institutional Ethical Committee of ICMR-National Institute of Immunohaematology, Mumbai. All procedures performed in studies involving human participants were as per the ethical standards of the institutional review board of the Institute and with the 1964 Helsinki declaration and its later amendments or comparable ethical standards.

\section{References}

1. Russo R, Esposito MR, Asci R, Gambale A, Perrotta S, Ramenghi U, lolascon A (2010) Mutational spectrum in congenital dyserythropoietic anemia type II: identification of 19 novel variants in SEC23B gene. Am J Hematol 85(12):915-920

2. Iolascon A, Andolfo I, Russo R (2020) Congenital dyserythropoietic anemias. Blood 136(11):1274-1283. doi: 10.1182/blood.2019000948

3. Heimpel H, Kellermann K, Neuschwander N, Högel J, Schwarz K (2010) The morphological diagnosis of congenital dyserythropoietic anemia: results of a quantitative analysis of peripheral blood and bone marrow cells. Haematologica 95(6):1034. https://doi.org/10.3324/haematol.2009.014563

4. Iolascon A, Russo R, Delaunay J (2011) Congenital dyserythropoietic anemias. Curr Opin Hematol 18(3):146-151. doi: 10.1097/MOH.0b013e32834521b0

5. Bianchi P, Fermo E, Vercellati C, Boschetti C, Barcellini W, lurlo A, Zanella A (2009) Congenital dyserythropoietic anemia type II (CDAll) is caused by mutations in the SEC23B gene. Hum Mutat 30(9):1292-1298. doi: 10.1002/humu.21077

6. Marwaha RK, Bansal D, Trehan A, Garewal G, Marwaha N (2003) Congenital dyserythropoietic anemia: clinical and hematological profile. Indian Pediatr 40(6):551-555

7. Sharma P, Das R, Bansal D, Trehan A (2015) Congenital dyserythropoietic anemia, type II with SEC23B exon 12 c. 1385 A $\rightarrow$ G mutation, and pseudoGaucher cells in two siblings. Hematology 20(2):104-107. doi: 10.1179/1607845414Y.0000000166

8. Das R, Jamwal M, Aggarwal A, Sharma P, Sachdeva MUS, Bansal D, Maitra A (2019) Spectrum of Genetic Defects and Phenotype-Genotype Correlation in DyserythropoieticAnemias. Bench to Bedside Approach in the Indian Scenario

9. Kedar P, Parmar V, Devendra R, Gupta V, Warang P, Madkaikar M (2017) Congenital dyserythropoietic anemia type II mimicking hereditary spherocytosis in Indian patients with SEC23B-Y462C mutations. Ann Hematol 96(12):2135-2139. doi: 10.1007/s00277-017-3116-5

10. Singleton BK, Ahmed M, Green CA, Heimpel H, Woźniak MJ, Ranjha L, King MJ (2018) CD44 as a potential screening marker for preliminary differentiation between congenital dyserythropoietic anemia type II and hereditary spherocytosis. Cytometry Part B: Clinical Cytometry 94(2):312-326. doi: 10.1002/cyto.b.21488

11. Singleton B, Bansal D, Varma N, Das R, Naseem S, Saikia UN, Ahmed M (2015) Homozygosity mapping reveals founder SEC23B-Y462C mutations in Indian congenital dyserythropoietic anemia type II. Clin Genet 88(2):195-197. doi: 10.1111/cge.12527

12. More TA, Kedar PS (2021) Genotypic analysis of SLC4A1 A858D mutation in Indian population associated with distal renal tubular Acidosis (dRTA) coupled with hemolytic anemia. Gene 769:145241. doi: 10.1016/j.gene.2020.145241 
13. Erali M, Wittwer CT (2010) High-resolution melting analysis for gene scanning. Methods 50(4):250-261. doi: 10.1016/j.ymeth.2010.01.013

14. Kedar PS, Colah RB, Kulkarni S, Ghosh K, Mohanty D (2003) Experience with eosin-5'-maleimide as a diagnostic tool for red cell membrane cytoskeleton disorders. Clin Lab Haematol. 25(6):373-6. doi: 10.1046/j.0141-9854.2003.00557.x. PMID: 14641141

15. Yue L, Lin M, Chen JT, Zhan XF, Zhong DS, Monte-Nguba SM, Yang LY (2014) Rapid screening for sickle cell disease by polymerase chain reaction-high resolution melting analysis. Mol Med Rep 9(6):2479-2484. doi: 10.3892/mmr.2014.2130

16. Wittwer CT, Reed GH, Gundry CN, Vandersteen JG, Pryor RJ (2003) High-resolution genotyping by amplicon melting analysis using LC Green. Clin Chem 49(6):853-860. doi: 10.1373/49.6.853

17. Montgomery JL, Sanford LN, Wittwer CT (2010) High-resolution DNA melting analysis in clinical research and diagnostics. Expert Rev Mol Diagn 10(2):219-240. doi: 10.1586/erm.09.84

18. Everman S, Wang SY (2019) Distinguishing Anuran species by high-resolution melting analysis of the COI barcode (COI-HRM). Ecology and evolution 9(23):13515-13520. doi: 10.1002/ece3.5808

\section{Figures}

F1

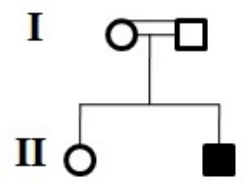

F6

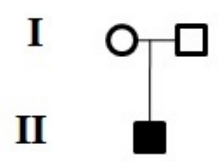

F2

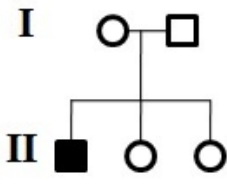

F7

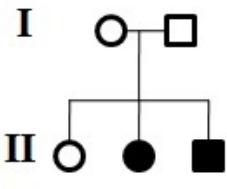

F3

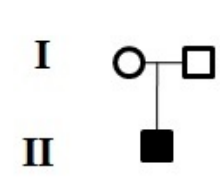

F8
F4

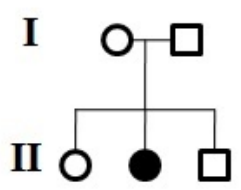

F9
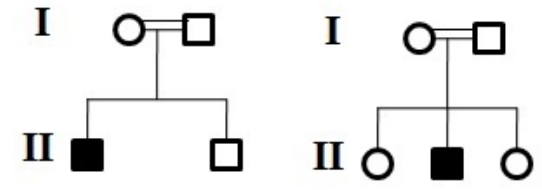

F5

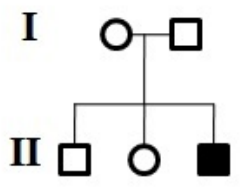

Figure 1

Pedigree structure and segregation analysis of families affected by congenital dyserythropoietic anemia (CDA). Individuals affected with CDA are indicated by a black filled circle (females) or square (males). 


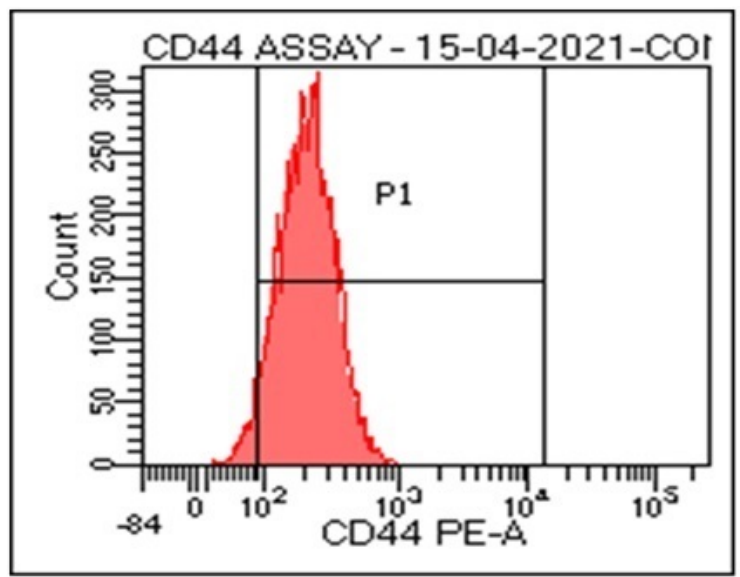

\begin{tabular}{|c|c|c|c|c|c|}
\hline \multirow{6}{*}{\multicolumn{2}{|c|}{$\begin{array}{l}\text { Experiment Name: } \\
\text { Specimen Name: } \\
\text { Tube Name: } \\
\text { Record Date: } \\
\text { \$OP: } \\
\text { GUID: }\end{array}$}} & \multicolumn{4}{|c|}{ CDMARKERS } \\
\hline & & & D44 ASSAY & $-15-04-20$ & \\
\hline & & & ONTROL & & \\
\hline & & & pr 15, 2021 & 3:23:27 PI & \\
\hline & & & dministrator & & \\
\hline & & & $1 \mathrm{dd} 9 \mathrm{fd} 9-34$ & $c 1-459 c-8 e$ & $74-52 c \ldots$ \\
\hline & & & CD44 P... & CD44 P... & CD44 P... \\
\hline Population & \#Events & \%Parent & Mean & Median & SD \\
\hline All Events & 10,977 & $\# \# \#$ & 236 & 193 & 396 \\
\hline $\mathrm{RBCs}$ & 9,207 & 83.9 & 209 & 190 & 116 \\
\hline $\bar{\nabla} \mathrm{P} 1$ & 8,551 & 92.9 & (220) & 199 & 113 \\
\hline
\end{tabular}

CD44 antibody binding for healthy individual

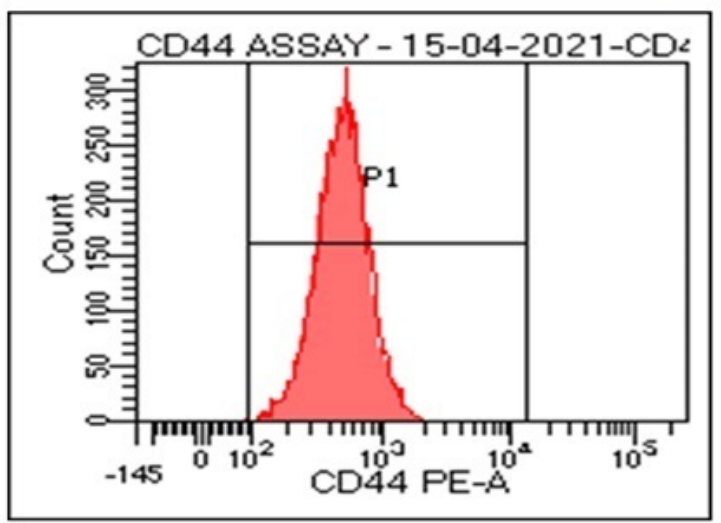

\begin{tabular}{|c|c|c|c|c|c|}
\hline \multicolumn{2}{|c|}{$\begin{array}{l}\text { Experiment Name: } \\
\text { Specimen Name: } \\
\text { Tube Name: } \\
\text { Record Date: } \\
\text { \$OP: } \\
\text { GUID: }\end{array}$} & \multicolumn{4}{|c|}{$\begin{array}{l}\text { CD MARKERS } \\
\text { CD44 ASSAY-15-04-2021 } \\
\text { CD44 2* } \\
\text { Apr 15, } 2021 \text { 3:24:31 PM } \\
\text { Administrator } \\
\text { fd23c282-54e1-4df0-9329-06 } 9 \text {... }\end{array}$} \\
\hline Population & \#Events & $\%$ Parent & $\begin{array}{r}\text { CD44 P... } \\
\text { Mean }\end{array}$ & $\begin{array}{l}\text { CD44 P... } \\
\text { Median }\end{array}$ & $\begin{array}{r}\mathrm{CD} 44 \mathrm{P} \ldots \\
\mathrm{SD}\end{array}$ \\
\hline All Events & 12,464 & \#\#\# & 610 & 450 & 1,004 \\
\hline$\square$ RBCs & 8,549 & 68.6 & 488 & 447 & 243 \\
\hline $\bar{\nabla} \mathrm{P} 1$ & 8,520 & 99.7 & 490 & 449 & 242 \\
\hline
\end{tabular}

CD44 antibody binding for patient suffering from CDA

Figure 2

The RBCs of CDA type Il patients showing an increased level of CD44 (MCF: 490) as compared to that of RBCs of a normal healthy individual (MCF: 220)
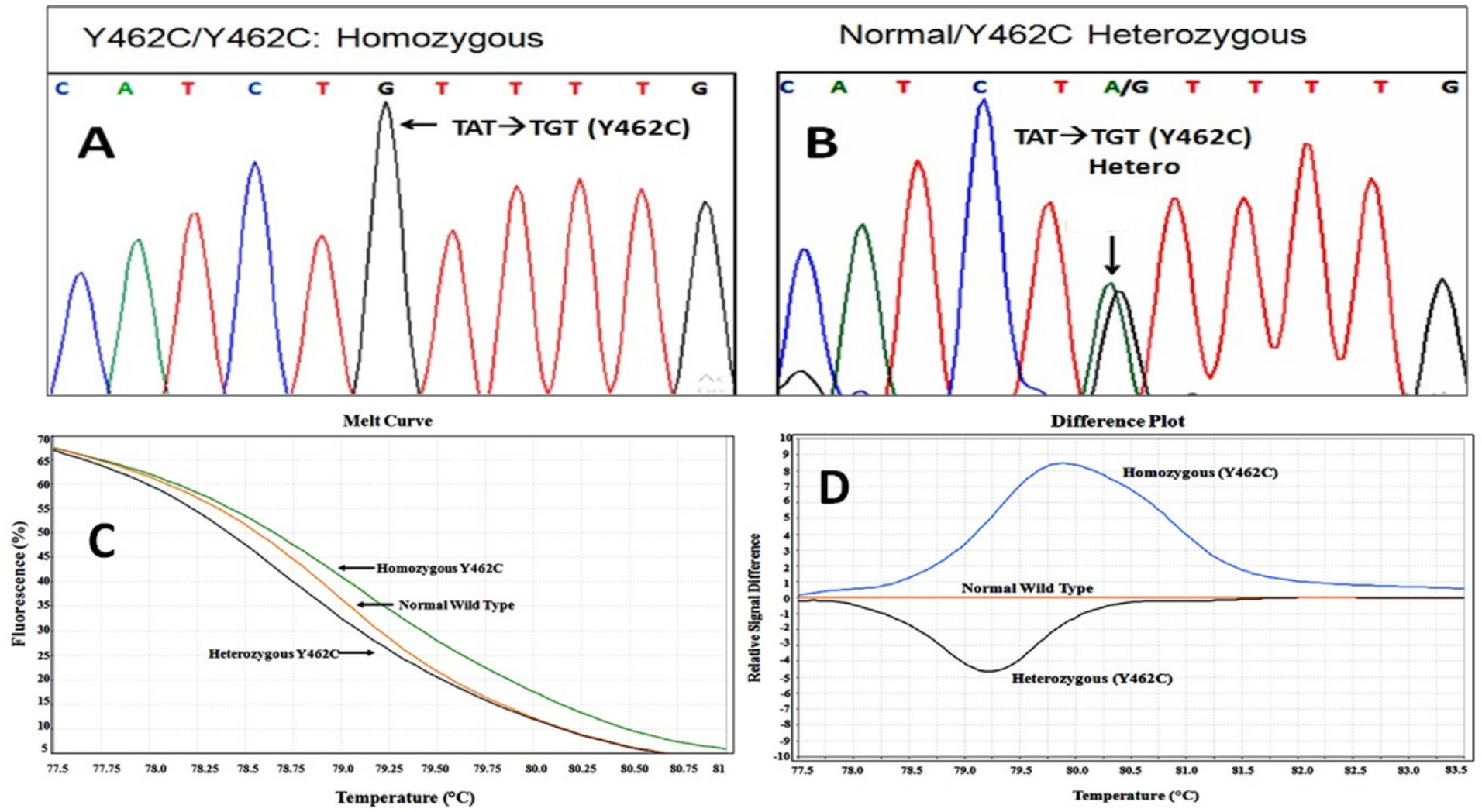
Figure 3

Sanger Sequencing of an amplified DNA fragment of exon 12 of SEC23B gene of patients suffering from CDA A) TGT/TGT (Homozygous). B) TAT/TGT (Heterozygous for CDA having normal phenotype) and HRM profile for genotypic differentiation. C) Melt curve showing homozygous (Y462C), heterozygous and wild type. D) Difference plot showing homozygous (Y462C), heterozygous and wild type 